\title{
REDUCTION OF OPERATING COSTS OF THE METALLURGICAL ENTERPRISE AT THE EXPENSE OF REFUSAL OF PURCHASED COMPRESSED AIR
}

\author{
Bechter L.A., Malyshko A.P. \\ Zaporizhzhya National University \\ Ukraine, Zaporozhye, Zhukovsky St. 66 \\ behter2018@ukr.net,alexml@i.ua \\ ORCID ID: 0000-0001-9931-9780
}

Key words:

inflationary processes, operating

costs, operating activities,

purchased compressed air, project, compressed air, strategic cost management.
The article investigates the issues of reducing the operating costs of the metallurgical enterprise by abandoning the purchased compressed air. The value and formation of operating costs at the production enterprise are considered. It is established that the most important in most situations are specific proposals to reduce operating costs of production activities. One of the most important areas of optimization of production operating costs at the investigated enterprise is the proposal to implement an investment project to reduce energy consumption in the production process. It is proposed to build a new compressor station, taking into account that in the process of production activities, namely in the technological process in the production of steel pipes, the studied enterprise uses a large amount of compressed air, which does not produce and whose production requires high energy consumption. Various alternative technical solutions for the use of turbochargers or screw compressors are considered. The development of other investment projects aimed at reducing the energy intensity of the enterprise as a whole has been formed. The cost of compressed air in the case of its production at its own compressor station has been calculated. Cost estimation were made in accordance of financial and economic indicators with the internal requirements of the enterprise.

\section{ЗНИЖЕННЯ ОПЕРАЦІЙНИХ ВИТРАТ МЕТАЛУРГІЙНОГО ПІДПРИСМСТВА ЗА РАХУНОК ВІДМОВИ ВІД ПОКУПНОГО СТИСНЕНОГО ПОВІТРЯ}

\section{Ключові слова:}

інфляційні процеси, операційні витрати, операційна діяльність, покупне стиснене повітря, проєкт, стиснене повітря, стратегічне управління витратами.

\section{Бехтер Л.А., Малишко О.П.}

Запорізький національний університет

Україна, м. Запоріжжся, вул.Жуковського 66

e-mail: behter2018@ukr.net, alexml@i.ua

ORCID ID: 0000-0001-9931-9780

У статті досліджуються питання зниження операційних витрат металургійного підприємства за рахунок відмови від покупного стисненого повітря. Розглянуто значення й формування операційних витрат на виробничому підприємстві. Встановлено, що найважливіше значення в більшості ситуацій мають конкретні пропозиції щодо зниження операційних витрат виробничої діяльності. Один із найважливіших напрямків оптимізації виробничих операційних витрат на досліджуваному підприємстві є пропозиція реалізувати інвестиційний проєкт щодо зменшення енергоспоживання у виробничому процесі. Запропоновано побудувати нову компресорну станцію, враховуючи те, що в процесі виробничої діяльності, а саме в технологічному процесі при виробництві стальних труб досліджуване підприємство використовує у великій кількості стиснене повітря, яке самостійно не виробляє i виробництво якого потребує великого енергоспоживання. Розглянуто різні альтернативні технічні рішення щодо використання турбокомпресорів або гвинтових компресорів. Сформовано розробку й інших інвестиційних проєктів направлених на зменшення енергоємності підприємства в цілому. Здійснено розрахунки вартості стисненого повітря в разі виробітки його на власній компресорній станції. Проведено розрахунки фінансово-економічних показників згідно з внутрішніми вимогами даного підприємства. 


\section{Statement of the problem}

The stability and development of any business entity in a competitive market significantly depends on the creation of an effective cost management system. The amount of costs is an important indicator for assessing the efficiency of the enterprise, including the determinant for the formation of the financial result of the metallurgical enterprise. Given this, the cost management process in terms of operating needs further detailed study and improvement. The development of metallurgical enterprises, namely the production of steel pipes taking into account the modern market environment requires a deeper study of methods and forms of economic management. To achieve the planned efficiency, competitiveness in the market, metallurgical enterprises with limited resources need to constantly compare costs and revenues from operating activities. The process of managing the economic activity of metallurgical enterprises is complicated by the fact that in recent years, uneven inflation has intensified. That is why it is necessary to solve the problem of obtaining maximum profit on the basis of cost management to increase the efficiency of both individual production lines and economic activities of metallurgical enterprises as a whole.

\section{Analysis of recent research and publications}

Under market conditions, the competitiveness of enterprises in order to achieve maximum profit must be ensured by a number of requirements. Achieving the goals set by management depends largely on the efficient use of all material and labor resources, which necessitates the study of the economic significance of the cost category and the gradual transition to a single cost management system. A significant contribution to the theory of research of strategic approaches and the choice of the most effective methods of its implementation was made by such wellknown foreign and Ukrainian scientists and practitioners as: I.A. Blank [1], V.P. Dyordiai [2], V.K. Makarovich [2], G. Fandel [3], O.K. Fokin [4], A.V. Cherep [5], K.V. Chichulin and I.O. Chapcha [6].

The authors mainly cover the general principles of analysis, its methods, as well as the results and role in management decisions. Much attention is paid to the study of theoretical issues of operating cost analysis.

Thus, Dyordyai V.P. and Makarovych V.K. argue that the analysis of effective management of operating costs requires a qualitative classification and procedure for determining costs. The authors summarize their own research in this area.

Chichulina K.V. and Chapcha I.O. on a concrete example prove the importance of strategic cost management and argue that it is one of the important ways to ensure the development of the enterprise and the competitiveness of its products on the market. The authors pay attention to the problem of minimizing costs in the total amount of net income on the basis of efficient use of production resources and structural changes in the quality of their management.

\section{Objectives of the article}

The purpose of the article is to substantiate the theoretical provisions and the introduction of practical rec- ommendations for reducing the operating costs of LLC "INTERPIPE NIKO TUBE" by abandoning the purchase of compressed air.

\section{The main material of the research}

Given the intensive development of our economy, metallurgical enterprises in the context of pipe production in determining the price of their products must take into account effective demand. In order to increase the demand of domestic and foreign consumers for their own products, increase competitiveness or simply ensure the existence of the market, many enterprises of the metallurgical complex need to choose to produce more profitable and profitable products that are in demand. If the company seeks to increase profits to achieve high economic performance and at the same time does not want to avoid a decrease in demand for its products, should not move by increasing prices. In all cases, to increase the profitability of products, companies should constantly optimize operating costs for production and sales of their products. Prices can only be reduced to a value that does not exceed the amount of these costs. Without calculation of operating costs, including and the full cost and profitability of products, it is impossible to determine the market price and effectively manage the process of profit formation. Formation of operating costs at the enterprises of metallurgical economy in the context of production of pipes is rather difficult technological process. In the context of the above calculation, the formation of operating costs is an important process, but in most situations, specific proposals to reduce operating costs of production activities are of paramount importance. One of such proposals at the company LLC "INTERPIPE NIKO TUBE" is a project to implement an investment project to reduce energy consumption in the production process. In the process of production activities, namely in the technological process in the production of steel pipes, the investigated enterprise uses a large amount of compressed air, the production of which requires high energy consumption.

According to the results of the analysis, starting from 2017 at the enterprise LLC "INTERPIPE NIKO TUBE" the cost of production of PRS № 2 (pipe rolling shop № 2) increased by almost 3 thousand UAH per ton. The company buys compressed air from a third-party supplier for $\$ 17 /$ thousand $\mathrm{m}^{3}$ and given the growth trend, the cost may increase to $\$ 22 /$ thousand $\mathrm{m}^{3}$. Given that INTERPIPE NIKO TUBE LLC together with PJSC NRZ (part of INTERPIPE Company) spends \$2.2 million / year on compressed air, and in the future these costs may increase to $\$ 3.1$ million / year such an investment project has a good chance of quick payback.

To enable the project to be implemented, the required amount of new equipment to cover the demand in compressed air was calculated. The results of the calculations are shown in fig. 1 .

For comparison, two alternative technical solutions were proposed - turbochargers and screw compressors. The results of the comparison are given in table. 1 .

Eliminate the shortage of compressed air production capacity in PRS № 2 is possible by transferring 2 screw compressors from PRS-7 to PRS-2 and purchasing 4 new screw compressors to complete the compressor station in 


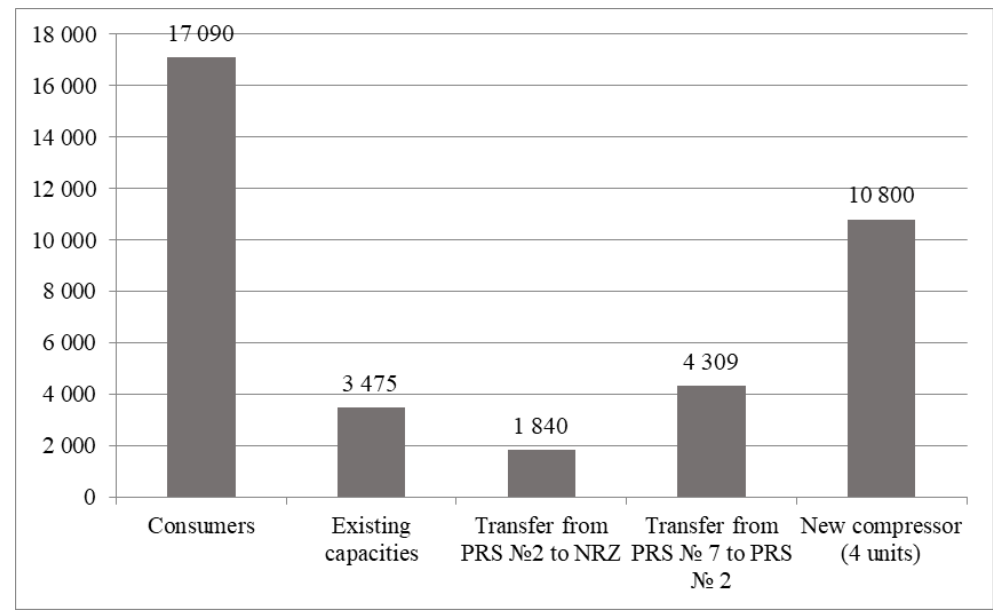

Fig. 1. Compressed air consumption and existing capacity, thousand $\mathrm{m}^{3} /$ month.

Table 1 - Comparison of technical solutions for project implementation

\begin{tabular}{|c|c|c|c|c|}
\hline Options & \multicolumn{2}{|c|}{ Screw compressors } & \multicolumn{2}{c|}{ Turbocharger } \\
\hline Measures & $\begin{array}{c}\text { Purchase of 4 screw } \\
\text { compressors + transfer } \\
\text { of 2 compressors from } \\
\text { PRS-7 + screw compres- } \\
\text { sor for NRZ }\end{array}$ & $\begin{array}{c}\text { Purchase } \\
\text { of 6 screw com- } \\
\text { pressors + screw } \\
\text { compressor for } \\
\text { NRZ }\end{array}$ & $\begin{array}{c}\text { Purchase } \\
\text { of 3 turbocharg- } \\
\text { ers in SM 5000+ } \\
\text { screw compressor } \\
\text { for NRS }\end{array}$ & $\begin{array}{c}\text { Acquisition } \\
\text { of turbochargers in } \\
\text { SM 5000 (2 for PRS-7 } \\
+2 \text { for PRS-2) + screw } \\
\text { compressor for NRZ }\end{array}$ \\
\hline CAPEX, thousand \$ & 481 & 585 & 1417 & 2395 \\
\hline OPEX (5 years), thousand \$ & 4756 & 4764 & 4567 & 5998 \\
\hline Cost of ownership, thousand \$ & 5237 & 5350 & 5984 & 8393 \\
\hline NPV, thousand dollars USA & 3773 & 3662 & 3042 & 1755 \\
\hline DPP, years & 0,49 & 0,61 & 1,72 & 2,84 \\
\hline Internal rate of return (IRR), $\%$ & $269 \%$ & $204 \%$ & $95 \%$ & $56 \%$ \\
\hline $\begin{array}{c}\text { Project implementation period, } \\
\text { months }\end{array}$ & 6 & 6 & 9 & 12 \\
\hline
\end{tabular}

PRS-2. This option is most effective in terms of speed of implementation and payback.

To determine the efficiency of the project, it is necessary to calculate the cost of compressed air in the case of its production at its own compressor station (it is necessary to buy 4 screw compressors and build a station on the area of PRS № 2). The calculations are given in table. 2.

The results of calculations show that the cost of compressed air of own production will be 2.6-3.3 times lower than purchased and will be $6.5-6.8 \$ /$ thousand $\mathrm{m}^{3}$. As a result of the implementation of this project, the company is able to save about $\$ 2$ million / year.

After determining the possible savings, the project budget was calculated (equipment was selected for the budget - screw compressor ECO 315, after the tender procedures, the equipment can be replaced with a similar on). The detailed budget of the project is given in table. 3 .

According to the results of the calculation, the project budget is $\$ 481$ thousand without VAT.

The project implementation period is 6 months from the moment of the decision to start the project implementation.

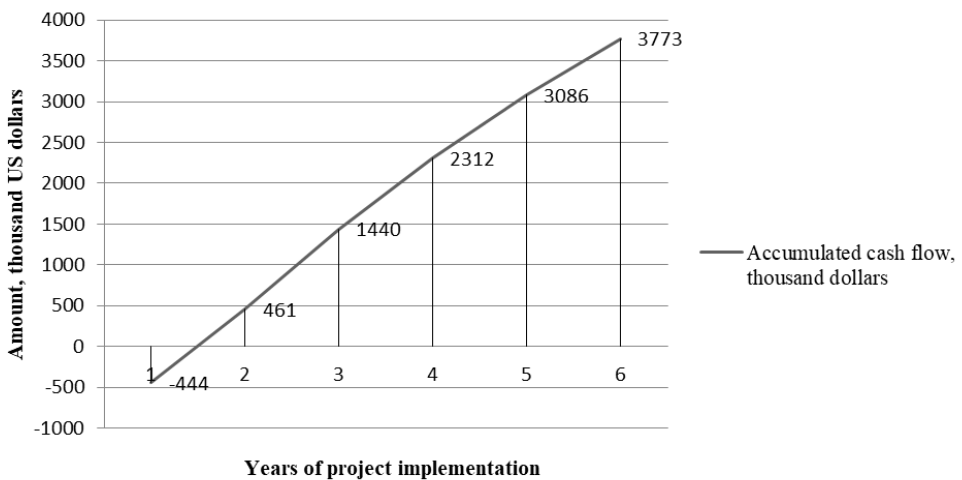

Fig. 2. Project performance indicators

To substantiate the calculations of financial and economic indicators in accordance with the internal requirements of LLC "INTERPIPE NIKO TUBE". These calculations are given in table. 4 , table. 5 and fig. 2

The main advantages of this project are a short implementation period - 6 months, and a quick payback - about six months. 
Table 2 - Calculations of the cost of compressed air of own production

\begin{tabular}{|c|c|c|c|c|c|c|c|}
\hline Name & Unit measurement & 2021 & 2022 & 2023 & 2024 & 2025 & 2026 \\
\hline $\begin{array}{c}\text { Production volume in PRS № } 2 \\
\text { (shipment) }\end{array}$ & $\mathrm{T}$ & 123337 & 150000 & 150000 & 150000 & 150000 & 150000 \\
\hline $\begin{array}{c}\text { Consumption of compressed air } \\
\text { PRS-2 + NRZ }\end{array}$ & thousand $\mathrm{m}^{3}$ / year & 130647 & 141680 & 141680 & 141680 & 141680 & 141680 \\
\hline $\begin{array}{l}\text { Consumption of compressed air } \\
\text { PRS-2 }\end{array}$ & thousand $\mathrm{m}^{3}$ / year & 125247 & 136280 & 136280 & 136280 & 136280 & 136280 \\
\hline NRC consumption forecast & thousand $\mathrm{m}^{3}$ & 5400 & 5400 & 5400 & 5400 & 5400 & 5400 \\
\hline $\begin{array}{l}\text { Specific consumption } \\
\text { of compressed air }\end{array}$ & $\mathrm{m}^{3} / \mathrm{t}$ & 1015 & 909 & 909 & 909 & 909 & 909 \\
\hline $\begin{array}{l}\text { The average cost of compressed } \\
\text { air PJSC "Energy Resources" }\end{array}$ & thousand $\$ /$ thousand $\mathrm{m}^{3}$ & 0,017 & 0,018 & 0,019 & 0,020 & 0,021 & 0,022 \\
\hline $\begin{array}{l}\text { Consumption of compressed air } \\
\text { consumed by PRS-2 }\end{array}$ & thousand $\$$ without VAT & 2160 & 2468 & 2592 & 2721 & 2857 & 3000 \\
\hline $\begin{array}{c}\text { Consumption of compressed air } \\
\text { consumed by NRZ }\end{array}$ & thousand \$ without VAT & 93 & 98 & 103 & 108 & 113 & 119 \\
\hline $\begin{array}{l}\text { Costs of compressed air from } \\
\text { PJSC "Energy Resources" }\end{array}$ & $\begin{array}{l}\text { thousand \$ without } \\
\text { VAT / year }\end{array}$ & 2254 & 2566 & 2694 & 2829 & 2971 & 3119 \\
\hline \multicolumn{8}{|c|}{ The cost of producing air on their own OPEX } \\
\hline Electricity costs & thousand $\$$ / year & 827 & 896 & 896 & 896 & 896 & 896 \\
\hline $\begin{array}{l}\text { Spare parts costs (spare tools } \\
\text { and accessories) }\end{array}$ & thousand $\$$ / year & 0 & 0 & 34 & 34 & 34 & 34 \\
\hline PA costs (salaries for operators) & thousand $\$$ / year & 15 & 15 & 15 & 15 & 15 & 15 \\
\hline Maintenance costs & thousand $\$$ / year & 13 & 13 & 13 & 13 & 13 & 13 \\
\hline Together OPEX & thousand \$ / year & 855 & 924 & 958 & 958 & 958 & 958 \\
\hline $\begin{array}{l}\text { The average annual cost of its } \\
\text { own compressed air }\end{array}$ & thousand $\$$ / year & 855 & 924 & 958 & 958 & 958 & 958 \\
\hline $\begin{array}{l}\text { The effect of compressed air } \\
\text { production }\end{array}$ & thousand \$ / year & 1398 & 1642 & 1737 & 1871 & 2013 & 2161 \\
\hline $\begin{array}{l}\text { Specific cost of own compressed } \\
\text { air }\end{array}$ & $\$ /$ thousand $\mathrm{m}^{3}$ & 6,5 & 6,5 & 6,8 & 6,8 & 6,8 & 6,8 \\
\hline Coefficient of reduction & Unit. measurement. & 2,6 & 2,8 & 2,8 & 3,0 & 3,1 & 3,3 \\
\hline
\end{tabular}

Table 3 - Project budget

\begin{tabular}{|c|c|c|}
\hline № & Name of equipment & TOTAL \\
\hline 1. & Basic equipment & 309 \\
\hline 1.1 & ECO 315 compressor (4 pcs.) & 247 \\
\hline 1.2 & Compressed air dehumidifier & 63 \\
\hline 2. & Auxiliary equipment & 78 \\
\hline 2.1 & KTP - 2 pcs. (2 KTP 2x1600) & 21 \\
\hline 2.2 & Vacuum switches with a set of protection & 9 \\
\hline 2.3 & Compressed air pipe with a set of valves & 10 \\
\hline 2.4 & Air ducts with gate valves & 5 \\
\hline 2.5 & Electrical equipment, cables & 12 \\
\hline 2.6 & Cold water meter & 0,1 \\
\hline 2.7 & Air flow meter & 6 \\
\hline 2.8 & Compressor parts & 15 \\
\hline 3. & Design works & 5 \\
\hline 3.1 & Coordination of the working project & 2 \\
\hline 3.2 & $\begin{array}{c}\text { Development of design and estimate docu- } \\
\text { mentation for compressor repair }\end{array}$ & 3 \\
\hline 4. & Construction and installation work & 81 \\
\hline
\end{tabular}

\begin{tabular}{|c|c|c|}
\hline 4.1 & Installation of ECO 315 compressors & 16 \\
\hline 4.2 & Installation of auxiliary equipment & 7 \\
\hline 4.3 & Commissioning work on the dehumidifier & 2 \\
\hline 4.4 & $\begin{array}{c}\text { Overhaul of the ATLAS COPCO GA 250 } \\
\text { compressor }\end{array}$ & 4 \\
\hline 4.5 & Overhaul of compressors with PRS-7 & 27 \\
\hline 4.6 & Installation of compressors from PRS-7 & 4 \\
\hline 4.7 & $\begin{array}{c}\text { Installation of the ATLAS COPCO GA 250 } \\
\text { compressor on HP3 }\end{array}$ & 2 \\
\hline 4.8 & Breeding of compressed air on the NRZ site & 20 \\
\hline 5. & Transportation costs & 2 \\
\hline 6. & VAT & 2 \\
\hline 7. & TOTAL INVESTMENT thousand \$ with VAT & 5 \\
\hline 8. & TOTAL FOR THE PROJECT thousand \$ & 481 \\
\hline 9. & VAT & 95 \\
\hline 10. & TOTAL INVESTMENT thousand \$ with VAT & 577 \\
\hline 11. & Undistributed reserve of thousands of \$ with VAT & 58 \\
\hline 12. & TOTAL FOR THE PROJECT thousand \$ & 635 \\
\hline
\end{tabular}


Table 4 - Indicators of financial efficiency of the project

\begin{tabular}{|l|c|c|c|c|c|c|}
\hline \multicolumn{1}{|c|}{ Indicator } & Investment & \multicolumn{3}{c|}{ Years of project implementation } \\
\cline { 2 - 6 } & $\mathbf{0}$ & $\mathbf{1}$ & $\mathbf{2}$ & $\mathbf{3}$ & $\mathbf{4}$ & $\mathbf{5}$ \\
\hline Investments, thousand \$ & $(444)$ & $(83)$ & & & & \\
\hline Total project income, thousand \$ & - & 2352 & 2694 & 2829 & 2971 & 3119 \\
\hline Reduce the cost of purchasing compressed air & - & 2352 & 2694 & 2829 & 2971 & 3119 \\
\hline Total project costs, thousand \$ & - & $(924)$ & $(958)$ & $(958)$ & $(958)$ & $(958)$ \\
\hline - electricity costs & - & $(896)$ & $(896)$ & $(896)$ & $(896)$ & $(896)$ \\
\hline - spare parts costs & - & - & $(34)$ & $(34)$ & $(34)$ & $(34)$ \\
\hline - salary costs for operators & - & $(15)$ & $(15)$ & $(15)$ & $(15)$ & $(15)$ \\
\hline- maintenance costs & - & $(13)$ & $(13)$ & $(13)$ & $(13)$ & $(13)$ \\
\hline $\begin{array}{l}\text { Net income before depreciation, interest and income tax } \\
\text { (EBI TDA) }\end{array}$ & - & 1428 & 1737 & 1871 & 2013 & 2161 \\
\hline- depreciation & - & $(44)$ & $(53)$ & $(53)$ & $(53)$ & $(53)$ \\
\hline Net income before taxes (EVT) & - & 1384 & 1684 & 1819 & 1960 & 2108 \\
\hline- income tax & - & $(249)$ & $(303)$ & $(327)$ & $(353)$ & $(380)$ \\
\hline Net Income & - & 1135 & 1381 & 1491 & 1607 & 1729 \\
\hline- amotisation & - & 44 & 53 & 53 & 53 & 53 \\
\hline Net cash flow, thousand \$ & $(444)$ & 1096 & 1433 & 1544 & 1660 & 1782 \\
\hline- net current cash flow & $(444)$ & 905 & 979 & 872 & 774 & 687 \\
\hline Accumulated discounted cash flow, thousand \$ & $(444)$ & 461 & 1440 & 2312 & 3086 & 3773 \\
\hline
\end{tabular}

\section{Conclusions}

This article considers the importance and formation of operating costs at the production plant. It is established that the most important in most situations are specific proposals to reduce operating costs of production activities. One of the most important areas of optimization of production operating costs at the researched enterprise LLC "INTERPIPE NIKO TUBE" is a proposal to implement an investment project to reduce energy consumption in the production process. Given the fact that in the process of production, namely in the technological process in the production of steel pipes, the company uses a large amount of compressed air, which does not produce and whose production requires high energy consumption, it was proposed to build a new compressor station. Various alternative technical solutions for the use of turbochargers or screw compressors were considered. The most profitable and most productive was the installation of 4 new screw compressors. The results of calculations show that the cost of compressed air of own production will be 2.6-3.3 times less than purchased and will be $6.5-6.8 \$ /$ thousand $\mathrm{m}^{3}$. As a result of the imple-
Table 5 - Summary indicators of financial efficiency of the project

\begin{tabular}{|c|c|}
\hline Indicator & Value \\
\hline The cost of capital & $21,0 \%$ \\
\hline Investment capital, thousand dollars USA & 528 \\
\hline NPV (net present value), thousand dollars USA & 3773 \\
\hline RI (profitability index) & 8,35 \\
\hline DPP (discounted payback period), years & 0,49 \\
\hline Internal rate of return (IRR), $\%$ & $269 \%$ \\
\hline
\end{tabular}

mentation of this investment project, the company LLC "INTERPIPE NIKO TUBE" will be able to save about $\$ 2$ million / year. According to the results of the calculation, the project budget is $\$ 481$ thousand without VAT. The main advantage of this project is a short implementation period - 6 months, and a quick payback - about six months. In addition, it is necessary to continue the development of other investment projects aimed at reducing the energy intensity of the enterprise as a whole.

\section{References}

1. Blank, I. A. (2000). Upravleniye pribylyu [Profit management]. Kyiv : Nika-Tsentr [in Ukrainian].

2. Dordiai, V.P. and Makarovych, V.K. (2019). "Analysis of operating expenses at the enterprises of the energy distribution industry", Bukhhalterskyi oblik, analiz, audyt ta opodatkuvannia: tezy Vseukrainskoi naukovo-praktychnoi on-line konferentsii zdobuvachiv vyshchoi osvity i molodykh uchenykh, prysviachenoi Dniu nauky [Accounting, analysis, audit and taxation : theses of the All-Ukrainian scientific and practical Online conference of higher education applicants and young scientists on the Day of science]. Zhytomyr. [in Ukrainian].

3. Fandel, H. (2000). Teoriia vyrobnytstva i vytrat [The theory of production and costs]. Kyiv : Takson [in Ukrainian].

4. Fokin, O.K. (2019). "Estimation of the costs of large industrial enterprises as the object of management and economic analysis", Visnyk ZhDTU. [in Ukrainian].

5. Cherep, A.V. (2006). Upravlinnia vytratamy subiektiv hospodariuvannia [Cost management of business entities], monograph. Kharkiv : VD "Inzhek". [in Ukrainian].

6. Chychulina, K.V. and Chapcha, I.O. (2019). "Formation of the optimal enterprise cost management system (for example PJSC "Poltava machine-building plant”)". Efektyvna ekonomika. [in Ukrainian]. 